\title{
Examination of Oral Health in Twins
}

\author{
İkiz Çocuklarda Ağız-Diş Sağlı̆̆ının İncelenmesi
}

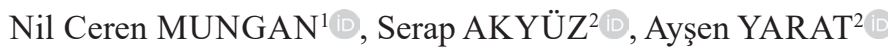

\begin{abstract}
Objectives: Nowadays in pediatric dentistry, a raise in oral-dental health studies in twins, had been observed with the increasing twin births. The aim of this study was to investigate the differences in terms of oral-dental health between twin children and singleton children.

Materials and Methods: A total of 180(105girls, 75 boys) children, 120 of them twins and 60 of them singleton, aged 4 to 14 years,were included to the study.All children were healthy.A questionnaire,with 30 items, including the educational level of the parents, age, gender and brushing habits of the children was applied.The df-t /df-s index for primary teeth and DMF-T / DMF-S index for permanent teeth were recorded.Streptococcus Mutans(SM) values of all children were recorded with the help of chairside kits.

Results: In-vitro fertilization(IVF) birth rate was $28.3 \%$ in the whole group.Furthermore, $33.3 \%$ of the children were monozygotic twins, $66.6 \%$ of them were dizygotic twins. There were no statistically significant relationship between the DMFT-dft values and daily teeth brushing of children( $p>0.05)$. A statistically significant correlation was found between mothers' education levels and DMFT values of children( $p>0.05)$.DMFT values of children whose mothers' were university graduates were found to be significantly lower than those of primary and high school graduates $(\mathrm{p}>0.05)$. In the monozygotic group; in $S M$ positive cases, the level of dft-dfs was statistically significantly higher than those of $S M$ negative cases $(\mathrm{p}<0.05)$.In dizygotic twins and singleton children;DMFT-DMFS levels were significantly higher in $S M$ positive cases than those of $S M$ negative cases $(\mathrm{p}<0.05)$. In singleton children the DMFT-DMFS values were statistically
\end{abstract}

Nil Ceren Mungan (四)

${ }^{1}$ Marmara University Facuty of Dentistry, Department of Pediatric Dentistry,Basibuyuk, Maltepe, Istanbul, Turkey, Mobile: 05071022469 e-mail: nilcerenmungan@gmail.com,

Serap Akyüz, Ayşen Yarat

${ }^{2}$ Marmara University Facuty of Dentistry, Department of Pediatric Dentistry, Department of Basic Medical Sciences Biochemistry, Istanbul, Subknitted / Gönderilme: 20.05.2019

Accepted/Kabul: 27.06.2019 significantly higher than twins whereas there was no statistically difference between monozygotic and dizygotic twins.

Conclusions: As a result of this study, despite that there was no significant difference in teeth brushing habits between twin and singleton children, the $S M$ values and DMFT-DMFS values were found higher in singleton children. Considering the multifactorial dynamics of dental caries formation, many factors such as saliva, nutrition, immune system, as well as oral hygiene habits should be considered as a whole.

Keywords: Twin children, dental caries, Streptococcus Mutans

Öz

Amaç:Günümüzde artan ikiz doğumlarıyla beraber çocuk diş hekimliğinde ikiz çocuklarda ağız-diş sağlığıyla ilgili çalışmalarda artış gözlenmiştir.Bu çalışmada ikiz çocuklar ile ikiz olmayan çocuklar arasında ağı-diş sağlığı açısından farklılıkların incelenmesi amaçlanmıştır.

Gereç ve Yöntemler:Araştırma kapsamında Marmara Üniversitesi Diş Hekimliği Fakültesi Pedodonti Anabilim Dalı Kliniği'ne başvuran, 4-14 yaş arasında, sistemik olarak sağlıklı, 120 ikiz ve 60 ikiz olmayan toplam 180 çocuk(105'i kı-75'i erkek) dahil edildi.Ebeveynlerin eğitim düzeyini, çocukların yaşını, cinsiyetini ve firçalama alışkanlıklarını içeren 30 soruluk anket uyguland1.Diş çürüklerini değerlendirmede süt dişleri için df-t/df-s, daimi dişler için DMF-T/DMF-S indeksi kullanıldı. Tüm çocukların Streptococcus Mutans(SM) değerleri hasta baş1 kitleriyle saptand1.

Bulgular:Tüm grupta in vitro fertilizasyon(IVF) ile doğum oran1 \%28,3 olarak bulundu.Ayrıca tek yumurta ikizi görülme oran1 $\% 33,3$ bulunurken, çift yumurta ikizi oran $1 \% 66,6$ olarak saptand1. İkiz ve ikiz olmayan çocuklarda günlük diş firçalama sıklığı ile DMFT-dft değerleri arasında istatistiksel olarak anlamlı bir ilişki bulunmadı( $\mathrm{p}>0.05)$. Anne eğitimi ile çocukların DMFT değerleri arasında istatistiksel olarak anlamlı birkorelasyon bulundu $(\mathrm{p}<0.05)$. Üniversite mezunu annelerin çocuklarının DMFT değerleri, ilkokul ve lise mezunlarından istatistiksel olarak anlamlı düzeyde düşük bulundu $(\mathrm{p}<0.05)$. Tek yumurta ikizlerinde; $S M$ pozitif olgularda $\mathrm{dft}$ - dfs düzeyi, $S M$ negatif olgulardan istatistiksel olarak anlamlı düzeyde yüksek bulundu( $(p<0.05)$.Çift yumurta ikizlerinde ve ikiz olmayan çocuklarda;SM pozitif olgularda DMFT-DMFS düzeyi, $S M$ negatif olgulardan istatistiksel olarak anlamlı düzeyde yüksek bulundu $(\mathrm{p}<0.05)$.İkiz olmayan çocuklarda ikiz çocuklara 
göre DMFT-DMFS değerleri daha yüksek bulunurken tek ve çift yumurta ikizleri arasında anlamlı farklılık görülmedi.

Sonuç: $\mathrm{Bu}$ çalışmanın sonucunda, ikiz ve ikiz olmayan çocuklar arasında diş firçalama sıklıkları açısından farklılık bulunmamasına rağmen, ikiz olmayan çocuklarda daha yüksek SM değerleri ve DMFT-DMFS değerleri saptandı.Diş çürüğü oluşumunun multifaktöriyel dinamikleri göz önüne alındığında, ağız hijyen alışkanlıklarının yanında tükürük, beslenme, immün sistem gibi birçok etken bir bütün olarak ele alınmalıdır.

Anahtar Kelimeler: İkiz çocuk, diş çürüğü, Streptococcus Mutans

\section{Introduction}

Oral diseases and dental caries are common health problems in our society as well as in the world [1]. Dental caries, one of the irreversible, preventable chronic diseases, is an important public health factor in many countries of the World [2]. According to the World Health Organization (WHO) data, it is recommended that the target values for $\mathrm{dft}$ and DMFT (decayed, filling and missing primary and permanent teeth) are planned according to the socioeconomic and sociocultural characteristics of the countries in the future [3] Factors such as educational level and income level affect the prevalence of dental caries [4].

Streptococcus Mutans (S.Mutans) is one of the main microorganisms that responsible for caries formation $[5$, 6]. Dental caries is a multifactorial process and result from demineralization of enamel and dentin due to the acid producing from microbial dental plaque (MDP) [7]

In the etiology of dental caries, which was first described by Paul Keyes in 1962 as diagrammatic, time, host, diet and microbiological factors have been extended with the addition of many factors up to date [6]. Many factors such as fluoride use, saliva composition are included in the diagram along with sociocultural and behavioral factors [6]. Factors such as tooth position and morphology, oral hygiene habits, age, immune system, sex, nutrition are also secondary factors responsible for caries formation [8].

One of the factors associated with the host is saliva which neutralize acid as a result of fermentation of carbohydrates. Low salivary $\mathrm{pH}$, low flow rate and low buffering, increases intraoral acidity and accelerates caries formation [9].

The effects of genetic factors, causing dental caries, have become more important today. With increasing twin births, studies on oral health have been observed in twin children in pediatric dentistry. Studies in twin children have great importance for the comparison of genetic and environmental factors on oral health [10].
The first studies to determine the relationship between dental caries and genetics were done with animal experiments. Studies on rats have shown that caries formation is affected by the genetic variation of the subject. It is proven that genetic factors have important roles in the caries mechanism of familial and twin studies on humans [11].

Nowadays, the number and frequency of multiple pregnancies, in the form of twin pregnancies, are increasing. One of the major factors that increase multiple pregnancies is the assisted reproductive techniques known as in vitro fertilization (IVF). The rate of infertility is increasing in the last 30-40 years. The most effective factors in that; the age of marriage and the increase in the age of fertility[12].

The aim of this study was to investigate the differences in terms of dental - oral health between twin children and singleton children.

\section{Materials and Methods}

A total of 180 healthy pediatric patients (60 pairs of them twins and 60 of them singleton) aged between 4-14 years were included to the study. The children were divided into two groups as study group (120 twins) and as control group (60 singleton children). The study group were also divided into two subgroups as monozygotic twins (40) and dizygotic twins (80).

All the patients were applied to Marmara University Faculty of Dentistry, Department of Pediatric Dentistry. Children who did not allow oral-dental examinations, children with a systemic disease or syndrome, and nonvolunteer families were excluded from the study.

This study was approved by Marmara University Faculty of Dentistry Ethics Committee with the protocol no: 10.09.2017-2017-124. Intra-oral examination was performed by a single investigator (NCM) under the reflector light. Information about demographic data including parents' educational level, children's age and gender, nutrition and brushing habits were collected through questionnaires from children and parents. The dft / dfs index values for primary teeth and DMFT / DMFS index values for permanent teeth were also recorded according to WHO criteria.

At 8:00-10:00 hours in the morning, non-stimulated saliva was collected by spitting into eppendorf tubes. Standardized chairside kits (The Saliva-Check Mutans kit - GC Corporation) were used for salivary S.Mutans measurement. 


\section{Statistical Analysis}

When evaluating the findings obtained in this study, IBM SPSS Statistics 22 for statistical analysis (SPSS IBM, Turkey) programs were used. In the evaluation of the data, descriptive statistical methods (mean, standard deviation, frequency), as well as Mann-Whitney $U$ test was used to compare the parameters that did not show normal distribution. Chi Square test and Continuity (Yates) correction were used to compare qualitative data. Spearman rho correlation analysis was used to examine the relationships between parameters which do not conform to normal distribution. Significance was evaluated as $p<0.05$.

\section{Results}

The average age of children is $9.73 \pm 2.24$ years and $58.3 \%$ of them were girls and $41.7 \%$ were boys. The in-vitro fertilization (IVF) rate was $28.3 \%$ for whole children. While $55.6 \%$ of them had S.Mutans positive and $44.4 \%$ were S.Mutans negative. Daily tooth brushing frequency ranges from 0 to 4 , with an average of $1.27 \pm 0.78$. DMFT values were $1.71 \pm 2.2$ (ranged from 0 to 12 ) while DMFS values were $2.43 \pm 3.91$ (ranged from 0 to 23 ). The $\mathrm{dft}$ values ranged from 0 to 15 with an average of $2.29 \pm 3.11$ and $\mathrm{dfs}$ values ranged from 0 to 18 with an average of $3.17 \pm 4.42$.

There was no statistically significant relationship between children's daily brushing frequency and DMFT-dft parameters $(p>0.05)$. There was a statistically significant relationship between the frequency of daily tooth brushing of the mothers'and $\mathrm{dft}$ values of children $(\mathrm{p}<0.05)$. There was no statistically significant relationship between the frequency of daily tooth brushing of mothers' and DMFT values children $(p>0.05)$ (Table1). There was a statistically significant difference in educational status of mothers' in terms of DMFT values of children $(p<0.05)$. The DMFT values of the children of mothers who were university graduates were found to be statistically lower than those of mothers with primary and high school graduates $(\mathrm{p}<0.05)$.

Table 1. Evaluation of daily tooth brushing frequencies of children and their mothers and correlation between DMFT and $\mathrm{dft}$ parameters of the whole children

\begin{tabular}{|l|l|l|l|}
\hline & & $\begin{array}{l}\text { Frequency of children's } \\
\text { daily tooth brushing }\end{array}$ & $\begin{array}{l}\text { Frequency of mothers'daily } \\
\text { tooth brushing }\end{array}$ \\
\hline DMFT & $\mathbf{r}$ & 0,013 & 0,055 \\
\hline & $\mathbf{p}$ & 0,860 & 0,462 \\
\hline dft & $\mathbf{r}$ & $-0,133$ & $\mathbf{- 0 , 1 7 6}$ \\
\hline & $\mathbf{p}$ & 0,076 & $\mathbf{0 , 0 1 8} *$ \\
\hline
\end{tabular}

Spearman Rho korelasyon analizi ${ }^{*} p<0.05$
The data were also analyzed under two groups as study group (120 twins $-66.7 \%)$ and as control group (60 singleton children-33.3\%). The IVF ratio of study (twins) group (36.4\%) was found to be significantly higher than control (singleton children) group $(1.7 \%)(\mathrm{p}<0.05)$. The rate of monozygotic twins was $33.3 \%$, while the rate of dizygotic twins was $66.6 \%$ in the study group.

DMFT and DMFS values of the study group were significantly lower than those of control group (Table 2) (p $<0.05)$. S. mutans positivity was significantly lower in the study group (50\%) than those of in the control group $(66.7 \%)(p<0.05)$.

Table 2. Evaluation of DMFT-DMFS-dft-dfs parameters beetween twins and singleton groups

\begin{tabular}{|l|l|l|l|l|}
\hline & & Twin group & Control group & p \\
\hline DMFT & Mean \pm SS & $1,47 \pm 2,09$ & $2,18 \pm 2,35$ & $\mathbf{0 , 0 2 2 *}$ \\
\hline & Median (IQR) & $0(0-2)$ & $2(0-4)$ & \\
\hline DMFS & Mean \pm SS & $1,98 \pm 3,38$ & $3,33 \pm 4,7$ & $\mathbf{0 , 0 1 5 *}$ \\
\hline & Median (IQR) & $0(0-2)$ & $2(0-4)$ & \\
\hline dft & Mean \pm SS & $2,01 \pm 2,75$ & $2,87 \pm 3,67$ & $\mathbf{0 , 2 2 4}$ \\
\hline & Median (IQR) & $0(0-4)$ & $1(0-5)$ & \\
\hline dfs & Mean \pm SS & $2,77 \pm 4,23$ & $3,98 \pm 4,71$ & $\mathbf{0 , 1 4 9}$ \\
\hline & Median (IQR) & $0(0-4)$ & $1,5(0-7,5)$ & \\
\hline
\end{tabular}

Mann Whitney $U$ test ${ }^{*} p<0.05$

In the study group; in patients with $S$. mutans positive, DMFT and DMFS levels were significantly higher than S.Mutans negative cases $(\mathrm{p}<0.05)$.

There was no statistically significant difference between monozygote and dizygotic groups in terms of DMFT, DMFS, $\mathrm{dft}$ and dfs values (Table 3 ) ( $\mathrm{p}>0.05$ ). The S.Mutans positivity rate in the monozygote group (35\%) was significantly lower than the dizygotic group $(57.5 \%)(\mathrm{p}<0.05)$.

Tablo 3. Evaluation of DMFT-DMFS-dft-dfs parameters beetween monozygotic and dizygotic groups

\begin{tabular}{|l|l|l|l|l|}
\hline \multicolumn{2}{|c|}{} & $\begin{array}{l}\text { Monozygotic } \\
\text { twins }\end{array}$ & $\begin{array}{l}\text { Dizygotic } \\
\text { twins }\end{array}$ & \multirow{2}{*}{ p } \\
\cline { 3 - 5 } & $\begin{array}{l}\text { Mean } \pm \text { SS } \\
\text { (median) }\end{array}$ & $\begin{array}{l}\text { Mean } \pm \text { SS } \\
\text { (median) }\end{array}$ & \\
\hline DMFT & Mean \pm SS & $1,75 \pm 2,74$ & $1,33 \pm 1,67$ & $\mathbf{0 , 9 0 5}$ \\
\hline & Median (IQR) & $0(0-2)$ & $0(0-2)$ & \\
\hline DMFS & Mean \pm SS & $2,58 \pm 4,56$ & $1,68 \pm 2,58$ & $\mathbf{0 , 9 0 6}$ \\
\hline & Median (IQR) & $0(0-2)$ & $0(0-2)$ & \\
\hline dft & Mean \pm SS & $1,68 \pm 2,69$ & $2,18 \pm 2,79$ & $\mathbf{0 , 2 6 8}$ \\
\hline & Median (IQR) & $0(0-2,75)$ & $1(0-4)$ & \\
\hline dfs & Mean \pm SS & $2,33 \pm 4,39$ & $2,99 \pm 4,16$ & $\mathbf{0 , 2 0 8}$ \\
\hline & Median (IQR) & $0(0-2,75)$ & $1(0-4,75)$ & \\
\hline
\end{tabular}

Mann whitney U test ${ }^{*} p<0.05$ 
In the monozygote group; in cases with S. mutans positive, $\mathrm{dft}$ and dfs levels were significantly higher than $S$. mutans negative cases $(\mathrm{p}<0.05)$. In dizygotic group; in children with $S$. mutans positive, DMFT and DMFS level is significantly higher than $S$.Mutans negative cases $(\mathrm{p}<0.05)$.

\section{Discussion and Conclusions}

Astrom and Jakobsen, emphasize the importance of families as role models for children that imitate their parents about their oral hygiene habits [13]. In our study, there was a statistically significant inverse correlation between the frequency of daily brushing of mothers' and their children's dft values. It was considered that similarly to Astrom and Jakobsen's study, the children, in our study, had imitated their mothers for their oral hygiene habits.

In the study of Borges et al. it has been reported that the prevalence of dental caries decreases as the education level of the mothers increases [14]. Similarly in our study, the lower rate of caries was found in the children whose mothers have university degrees. It was also confirmed that the education level of the families is an important factor on oral and dental health. The children and their parents should be adequately trained to determine their dental treatment needs. The studies that determine the condition and treatment needs of dental caries in the community will improve oral and dental health and ensure the development of protective policies [13].

The results of our study show that singleton children have an increased susceptibility to dental caries incidance when compared with twin children according to DMFT index data and S.Mutans colonization. On the authority of this study, it is estimated that twin siblings may effect each other positively about the oral hygiene and nutritional behaviours. This study will be more comprehensive when researched with co-twins.

According to Subramaniam et al. DMFT values and oral hygiene index were evaluated in 58 dizygotic pairs and 71 pairs of monozygotic twins. There was no significant difference between monozygotic and dizygotic twins in terms of DMFT-dft data [15]. In our study, also, there was no significant difference between monozygotic and dizygotic twins in terms of DMFT-dft data. The exact reason for the similarity of that results between monozygotic and dizygotic twins is not clear so the study should be extended with more children and salivary parameters.
According to Sümer et al's studies published in 2013, $14.6 \%$ of twins births were determined as IVF and this rate was $29.1 \%$ in our study [16]. Over the last years, it is estimated that the increased use of fertility treatments has been associated with rise in the rate of multiple births [17].

As a result of this study, despite that there was no significant difference in teeth brushing habits between twin and singleton children, the S.Mutans values and DMFTDMFS values were found higher in singleton children. Considering the multifactorial dynamics of dental caries formation, many factors such as saliva, nutrition, immune system, as well as oral hygiene habits should be considered as a whole.

\section{Acknowledgements}

This study was supported by Marmara University Scientific Research Projects Unit-BAPKO (SAG-CDRP-131.217.0649).

\section{REFERENCES}

1. K. Esra, N. Özalp, Çocuklara Streptokokkus mutans geçişinin değerlendirilmesi: Etkili faktörler ve enfektivite penceresi, Atatürk Üniversitesi Diş Hekimliği Fakültesi Dergisi 25(11) 71-76.

2. E. Joury, E. Bernabe, W. Sabbah, K. Nakhleh, K. Gurusamy, Systematic review and meta-analysis of randomised controlled trials on the effectiveness of school-based dental screening versus no screening on improving oral health in children, Journal of dentistry 58 (2017) 1-10.

3. E.U. Çelik, D.B. Çelik, U.D.S. Önal, D.A. Örmeci, D.H. Ulutaş, Isparta İlindeki 11-12 YaşindakI Çocuklarin Diş Çürüğü Ve Florozis Prevalansinin Değerlendirilmesi, Atatürk Üniversitesi Diş Hekimliği Fakültesi Dergisi 2010(3) (2010) 170-175.

4. Y. Okutan, M.B. Dönmez, M.T. Yücel, Sosyoekonomik şartların diş hekimliği öğrencilerinin ağız sağlı̆̆ına olan etkisi: Anket çalışması, Selcuk Dental Journal 4 (2017) 5967.

5. F.Y. Çakır, S. Gürgan, N. Attar, Çürük mikrobiyolojisi, H Diş Hek Fak Derg 34(3) (2010) 78-91.

6. S. Bektaş, M. Turgut, Çocuk Diş Hekimliğinde Çürük Risk Tayini, Ondokuz Mayıs Üniversitesi Diş Hekimliği Fakültesi Dergisi 11(3) (2010) 109-118.

7. C.K.-Y. Yiu, N.M. King, An overview of dental cariespreventives approaches for children, Hong Kong Dental Journal 8 (2011) 29-39.

8. B. Koçanalı, A.T. Ak, D. Çoğulu, Çocuklarda diş çürüğüne neden olan faktörlerin incelenmesi, Pediatric Research 1(2) (2014) 76-9. 
9. B. Preethi, D. Reshma, P. Anand, Evaluation of flow rate, $\mathrm{pH}$, buffering capacity, calcium, total proteins and total antioxidant capacity levels of saliva in caries free and caries active children: an in vivo study, Indian Journal of Clinical Biochemistry 25(4) (2010) 425-428.

10. D. Bartlett, C. Ganss, A. Lussi, Basic Erosive Wear Examination (BEWE): a new scoring system for scientific and clinical needs, Clinical oral investigations 12(1) (2008) 65-68.

11. M. Bayram, F. Seymen, Diş Çürüğüne Genetik Yaklaşım, Turkiye Klinikleri. Dishekimligi Bilimleri Dergisi 20(2) (2014) 129-135.

12. R.A. Jackson, K.A. Gibson, Y.W. Wu, M.S. Croughan, Perinatal outcomes in singletons following in vitro fertilization: a meta-analysis, Obstetrics \& Gynecology 103(3) (2004) 551-563.

13. E. Karaağaç, Ç. Küçükeşmen, Çocukların ve Ebeveynlerinin Oral Hijyen Alışkanlık (OHA) Düzeylerinin Karşılaştırılması ve Değerlendirilmesi, SDÜ Tıp Fakültesi Dergisi 25(1) (2018) 42-49.

14. H.C. Borges, C.A.S. Garbín, O. Saliba, N.A. Saliba, S.A.S. Moimaz, Socio-behavioral factors influence prevalence and severity of dental caries in children with primary dentition, Brazilian oral research 26(6) (2012) 564-570.

15. P. Subramaniam, K.G. Babu, B. Vardhana, Assessment of dental caries and oral hygiene status among twins, Journal of Forensic Science and Medicine 4(1) (2018) 18.

16. D. Sümer, M. Çetin, A. Yenicesu, A. Yanık, Spontan ve IVF ikiz gebeliklerin obstetrik ve perinatal sonuçlarının karşılaştırılması, Cumhuriyet Medical Journal 35(4) (2013) 526-531.

17. A.D. Kulkarni, D.J. Jamieson, H.W. Jones Jr, D.M. Kissin, M.F. Gallo, M. Macaluso, E.Y. Adashi, Fertility treatments and multiple births in the United States, New England Journal of Medicine 369(23) (2013) 2218-2225. 